\title{
PENGETAHUAN SIKAP DAN PERILAKU REMAJA PUTRI TERHADAP PERSONAL HYGINE PADA SAAT MENSTRUASI DI SMP NEGERI 3 PARONGPONG KABUPATEN BANDUNG BARAT
}

\author{
Jane Mona Lisa Simanjuntak*, Nurhayati Siagian \\ Fakultas Ilmu Keperawatan Universitas Advent Indonesia, Jl. Kolonel Masturi no 288, \\ Parongpong, Bandung Barat \\ *E-mail: janemonalisa11@gmail.com
}

\begin{abstract}
Knowledge of teenage girl attitudes and behavior towards Personal hygiene during menstruation at SMP Negeri 3 Parongpong, West Bandung Regency. Personal hygiene at the time of menstruation should be observed in order to avoid the health problems of reproductive organs. This research aims to know the knowledge, attitudes and behavior of the students to personal hygiene during menstruation in Junior High School 3 Parongpong District, West Bandung. The research method is a quantitative descriptive with purposive sampling method. A research sample is a students of junior high school 3 Parongpong as many as 92 girls. Data collection uses 25 questions for knowledge, 20 statements for attitudes and 25 statements for behavior. The results of the study found that the respondent had a lack of knowledge about personal hygiene during menstruation (95.7\%). The attitude of students supports personal hygiene during menstruation (51.5\%). Students who has a behavior relatively poor about personal hygiene during menstruation (68.5\%). Hopefully this research can be the input and guidance for the school to provide facilities in schools such as handwashing, tissue, and the availability of sanitary pads in women's toilets, nurses and local health workers provide health promotion to the young women about the importance of personal hygiene during menstruation.
\end{abstract}

Keywords: Attitude, Behavior, Knowledge, Menstruation, Personal hygiene.

\begin{abstract}
Abstrak
Personal hygiene pada saat menstruasi perlu diperhatikan supaya terhindar dari masalah kesehatan organ reproduksi. Penelitian ini bertujuan untuk mengetahui gambaran pengetahuan, sikap dan perilaku siswi terhadap personal hygiene pada saat menstruasi di SMP Negeri 3 Parongpong Kabupaten Bandung Barat. Metode penelitian adalah deskriptif kuantitatif dengan metode pengambilan sampel purposive sampling. Sampel penelitian adalah siswi SMP Negeri 3 Parongpong sebanyak 92 siswi. Pengumpulan data menggunakan 25 pertanyaan untuk pengetahuan, 20 pernyataan untuk sikap dan 25 pernyataan untuk perilaku yang telah diadaptasi. Hasil penelitian yang di dapati yaitu responden memiliki pengetahuan yang kurang mengenai personal hygiene pada saat menstruasi $(95,7 \%)$. Sikap siswi yang mendukung personal hygiene ketika menstruasi $(51,5 \%)$. Siswi yang memiliki perilaku kurang baik mengenai personal hygiene pada saat menstruasi $(68,5 \%)$. Diharapkan penelitian ini bisa menjadi masukan dan pedoman untuk pihak sekolah dalam memberikan fasilitas di sekolah seperti tempat mencuci tangan, tisu, dan ketersediaan pembalut di toilet wanita, perawat dan tenaga kesehatan setempat memberikan promosi kesehatan kepada remaja putri tentang pentingnya personal hygiene pada saat menstruasi.
\end{abstract}

Kata Kunci: Menstruasi, Personal hygiene, Pengetahuan, Perilaku, Sikap

\section{Pendahuluan}

Personal hygiene merupakan tindakan seseorang dalam menjaga, merawat dan memelihara kebersihan seluruh anggota tubuhnya, salah satunya dengan melakukan perawatan organ reproduksi pada saat menstruasi (Andarmoyo, 2012). Masa remaja adalah masa dimana mulai terjadi adanya perubahan pada fisik, psikis, serta emosi. Masa ini juga menjadi masa peralihan anak-anak 
beranjak menuju dewasa serta matangnya organ reproduksi disebut masa pubertas atau puberty. Salah satu tanda masa pubertas pada perempuan adalah terjadinya menstruasi. Menstruasi untuk pertama kalinya disebut juga Menarche (Widyastuti et al., 2009). Sangat penting untuk melakukan personal hygiene serta memelihara kesehatan organ reproduksi. Hal tersebut dikarenakan ketika haid pembuluh darah yang ada di rahim sangat sensitif. Sehingga akan mudah sekali untuk terinfeksi ketika kuman masuk kedalam saluran rahim dan menimbulkan penyakit pada alat reproduksi. (Rosyida, 2019) Remaja putri yang belum melaksanakan perilaku personal hygiene dengan benar saat menstruasi dapat mengakibatkan timbulnya gangguan pada saluran reproduksi (kemih), kanker serviks, keputihan, dan penyakit reproduksi yang sejenisnya (Nugroho, 2013).

Merawat diri sendiri pada saat menstruasi sangat di butuhkan guna memelihara, menjaga kesehatan organ reproduksi, alternatif tersebut seperti melakukan penggantian pembalut setelah 3-4 jam sekali, membersihkan diri setiap hari ketika dysmenorrhea, membersihkan area genital mulai dari depan (vagina) menuju ke belakang (anus) setelah buang air besar atau kecil, melakukan aktifitas fisik seperti olahraga pergi ke sekolah, mencukupi asupan makanan dengan sayur dan buah-buahan mengandung kaya zat besi dan kalsium (Santina et al., 2013).

Pengetahuan setiap individu tentang personal hygiene memberikan pengaruhi besar terhadap sikap dan perilaku seseorang dalam menjaga, memelihara serta merawat kesehatan reproduksi. Sikap positif dan negatif tentang pengetahuan yang didapat tergantung dari pemahaman individu tersebut, bila individu memiliki sikap yang positif itu akan mendorong keinginan individu melakukan perilaku dalam kehidupannya sehari-hari (Pythagoras, 2017).

Setelah dilakukan survei pendahuluan pada tanggal 18 Februasi 2020 kepada siswi SMP Negeri 3 Parongpong dari 10 siswi yang di wawancarai mengatakan mereka belum memahami dengan baik tentang personal hygiene ketika terjadi menstruasi seperti kurang tepatnya cara membasuh organ intim dengan benar, lama penggunaan pembalut yang salah saat menstruasi. Untuk dapat melakukannya perlu pengetahuan sikap dan perilaku yang benar tentang pentingnya perawatan diri saat menstruasi untuk memelihara dan meningkatkan kualitas hidup individu.

Berdasarkan permasalahan yang ada, peneliti ingin melakukan penelitian tentang bagaimana gambaran pengetahuan, sikap maupun perilaku remaja putri terhadap personal hygiene di SMP Negeri 3 Parongpong Kabupaten Bandung Barat.

\section{Metode Penelitian}

Desain penelitian yang dipilih oleh penulis untuk penelitian ini adalah metode deskriptif kuantitatif. Sedangkan populasi yang digunakan oleh peneliti untuk mendukung proses penelitian adalah seluruh siswi kelas 8 SMP Negeri 3 Parongpong. Teknik yang dipilih penulis untuk mengambil data penelitian adalah teknik purposive sampling dengan menggunakan kriteria populasi yaitu siswi berusia 13-15 tahun, yang dalam kondisi sudah mengalami pubertas atau menstruasi, dan siswi yang berkenan berperan sebagai responden dalam penelitian ini, sehingga total responden yang mengikuti penelitian ini berjumlah 92 responden. Data ini dikumpulkan dengan cara menyebarkan instrumen kepada responden sesuai karakteristik Instrumen yang digunakan berupa kuesioner yang telah diadaptasi dan diedit dari Yustin 2019 dengan pengetahuan berbentuk multiple choice sebanyak 25 pertanyaan, untuk sikap dan perilaku menggunakan skala Likert sebanyak 20 dan 25 pernyataan dengan uji rehabilitas masing-masing nilai 0,726, 0,708, dan 0,716 yang berarti kuesioner ini reliabel untuk digunakan. Analisa data penelitian ini menggunakan mean dan STD karena sikap dan perilaku merupakan data distribusi normal. Pengetahuan menurut skornya terbagi menjadi dua kategori, diantaranya adalah pengetahuan baik jika total skor yang didapat $\geq 75 \%$ dan pengetahuan kurang baik jika total skor $<75 \%$. Sikap menurut skornya dapat dibagi menjadi dua kategori, diantaranya adalah sikap mendukung yaitu yang memiliki skor > rata-rata dan sikap tidak mendukung yaitu yang memiliki skor < rata-rata. Selain itu, perilaku juga dapat dibagi menjadi dua kategori, yaitu perilaku baik apabila skor > rata-rata dan perilaku kurang baik apabila skor < rata-rata.

\section{Hasil}

Berdasarkan dari hasil penelitian, didapatkan hasil data sebagai berikut:

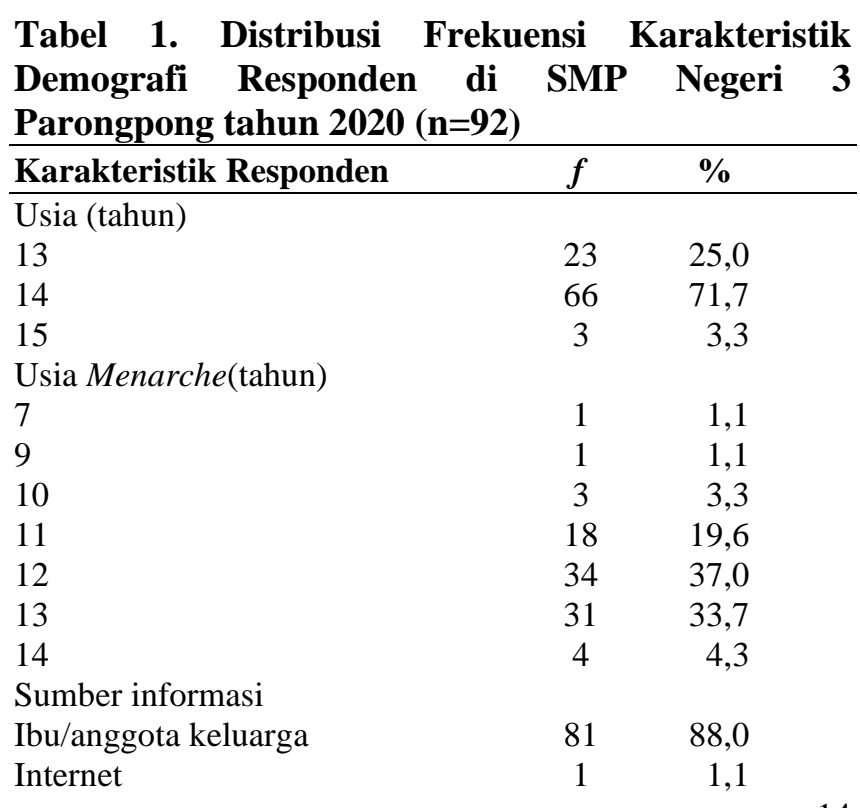


Teman

Petugas Kesehatan

Guru

$\begin{array}{cr}5 & 5,4 \\ 2 & 2,2 \\ 3 & 3,3 \\ & \\ 1 & 1,1 \\ 6 & 6,5 \\ 3 & 3,3 \\ 9 & 9,8 \\ 1 & 1,1 \\ 64 & 69,6 \\ 8 & 8,7\end{array}$

Berdasarkan tabel 1, Usia menarche dari responden yang paling banyak yaitu saat usia 12 tahun( 37,0\%). Informasi yang didapatkan paling banyak adalah bersumber dari Ibu/orangtua $(88,0 \%)$ dan teman $(5,4 \%)$. Keluhan menstruasi yang paling banyak dirasakan oleh responden adalah $\mathrm{Kram} /$ nyeri perut $(69,6 \%)$, gatal $(9,8 \%)$, pusing $(8,7 \%)$, pegal-pegal $(6,5 \%)$.

Tabel 2. Distrubusi Frekuensi Pengetahuan Terhadap Personal hygiene Pada Saat Menstruasi Remaja Putri SMP Negeri 3 Parongpong Tahun $2020(\mathbf{n}=92)$

\begin{tabular}{llr}
\hline Variabel & $\boldsymbol{f}$ & \% \\
\hline Pengatahuan & & \\
Baik & 4 & 4,3 \\
Kurang baik & 88 & 95,7 \\
\hline
\end{tabular}

Berdasarkan tabel 2 pengetahuan responden terhadap personal hygiene pada saat terjadi menstruasi sebagian besar dalam kategori kurang baik yaitu sebesar 88 responden $(95,7 \%)$.

Tabel 3. Distribusi Frekuensi Sikap terhadap Personal hygiene Pada Saat Menstruasi Remaja Putri SMP Negeri 3 Parongpong Tahun 2020 $(\mathbf{n}=92)$

\begin{tabular}{lll}
\hline Variabel & $\boldsymbol{f}$ & \% \\
\hline Sikap & & \\
Mendukung & 47 & 51,1 \\
Tidak mendukung & 45 & 48,9 \\
\hline
\end{tabular}

Berdasarkan Tabel 3, sikap responden terhadap personal hygiene saat menstruasi adalah kategori mendukung terdapat 47 responden $(51,1 \%)$.

Tabel 4. Distribusi Frekuensi Perilaku Terhadap Personal hygiene Saat Menstruasi Remaja Putri SMP Negeri 3 Parongpong $2020(n=92)$

\begin{tabular}{lcc}
\hline Variabel & $\boldsymbol{f}$ & \% \\
\hline Perilaku & & \\
Baik & 29 & 31,5 \\
Kurang baik & 63 & 68,5 \\
\hline
\end{tabular}

Berdasarkan Tabel 4, perilaku responden terhadap personal hygiene ketika terjadi menstruasi sebagian besar dalam kategori kurang baik sebesar 63 responden $(68,5 \%)$.

\section{Pembahasan}

\section{A. Gambaran Pengetahuan Terhadap Personal hygiene Pada Saat Menstruasi Remaja Putri SMP Negeri 3 Parongpong Kabupaten Bandung Barat}

Hasil penelitian didapati bahwa sebanyak $95,7 \%$ responden memiliki pengetahuan yang kurang baik mengenai personal hygiene ketika menstruasi. Notoatmodjo, (2012) berpendapat yaitu pengetahuan adalah hasil tahu yang berkesan didalam pikiran seseorang. Hasil tahu ini terjadi ketika seseorang telah menggunakan pancainderanya terkhusus dalam membentuk perilaku seseorang.

Ada beberapa faktor yang saat ini dapat berpengaruh kurang baik terhadap hasil kuesinoner responden terhadap personal hygiene ketika terjadi menstruasi. Faktor-faktor tersebut antara lain adalah pengalaman, dan sumber informasi yang minim didapat oleh responden. Menurut Brunner, proses terbentuk pengetahuuan terdiri tiga aspek. Diantaranya adalah proses mendapatkan informasi, proses evaluasi, dan proses transformasi (Mubarak, 2011).

Faktor lain yang mempengaruhi kurang baiknya pengetahuan yang diperoleh responden adalah informasi yang dimiliki para responden mungkin hanya sebatas tingkat pengetahuan pertama yaitu tahu (know). Hasil dari pertanyaaan-pertanyaan mengenai defenisi menstruasi, siklus menstruasi, gangguan dalam menstruasi, penggunaan pembalut yang benar sebagian besar responden menjawab dengan salah, sehingga belum adanya pemahaman yang mendalam oleh para responden dalam hal pengaplikasian pengetahuan yang telah mereka dapatkan kedalam kehidupan masing-masing.

Dari faktor pengalaman pun dapat mempengaruhi pengetahuan yang mereka dapatkan, karena pengalaman pribadi responden terhadap menstruasi masih merupakan hal baru yang mereka dapatkan. Rata-rata usia dari responden yang mengisi kuesioner adalah 14 tahun dan karakteristik responden adalah usia 12 tahuan (37\%) sehingga para responden belum terlalu berpengalaman dalam mengatasi hal-hal mengenai personal hygiene saat menstruasi. Berdasarkan sumber informasi yang didapat, sebagian besar responden mendapat informasi dari ibu/orangtua (88\%) dan teman $(5,4 \%)$. Remaja putri lebih condong mendapatkan informasi dari sumber-sumber seperti guru, orangtua, media maupun teman. Sesuai dengan penelitian (Eswi et al., 2012) bahwa ibu mereka 
memberikan informasi mengenai hal tentang menstruasi paling banyak yaitu sebesar (53\%). Berapa penelitian menyebutkan bahwa ibu merupakan sumber informasi. Penelitian yang dilakukan oleh Solehati (2015) menunjukkan bahwa sebanyak $82 \%$ dari total responden remaja putri memperoleh sumber informasi tentang kesehatan melalui ibu mereka masing-masing.

Pengetahuan yang didapatkan setiap orang berbeda-beda, tergantung kepada seberapa jauh pengetahuan ibu mereka mengenai menstruasi. Berdasarkan hasil penelitian ini, dari $88 \%$ responden yang mendapat informasi dari ibu atau keluarga mereka, 96,29\% nya memiliki pengetahuan yg kurang baik mengenai personal hygiene sat menstruasi. Seorang ibu harus mampu memberikan motivasi maupun support kepada anak perempuannya sehingga merasa nyaman dan aman ketika melalui proses menstruasi pertama. Seorang ibu harus menjelaskan dan memberikan informasi mengenai menstruasi antara lain yang berkaitan dengan proses menstruasi baik dari segi biologis, dan memberikan dukungan moral. Sebagai tenaga kesehatan, sebaiknya memberikan edukasi mengenai personal hygiene pada saat menstruasi untuk membantu meningkatkan pengetahuan remaja putri karena dari hasil temuan menunjukkan defisit pengetahuan terhadap personal hygiene pada saat menstruasi.

Ketika seorang remaja telah mengalami perkembangan sosial, seorang remaja tersebut akan secara langsung mendapatkan pengaruh dari rekan-rekan sebaya (Desmita, 2009). Seorang remaja ketika telah mengalami perkembangan sosial akan lebih sering mendapatkan persetujuan (approvall) maupun penerimaan (acceptance) dari rekan sebaya mereka. Oleh karena itu, saat ini sudah banyak remaja yang sudah mau untuk bersikap lebih terbuka kepada teman sebayanya (Poltekkes Depkes Jakarta I, 2010). Berdasarkan hasil penelitian ini, sebanyak 5,4\% responden yang mendapat informasi dari temannya.

Solehati, (2018) telah melakukan penelitan mengenai sejauh apa pengetahuan yang dimiliki mengenai personal hygiene ketika terjadi menstruasi. Dari penelitian yang dilakukan, diperoleh bahwa $100 \%$ mempunyai pengetahuan yang tidak cukup bagus mengenai personal hygiene ketika proses menstruasi. Sedangkan Liza, (2019) telah meneliti hal yang setara dengan penelitian oleh Solehati (2018) dan diperoleh bahwa sebesar $65,5 \%$ belum memiliki pengetahuan yang baik mengenai personal hygiene pada ketika terjadi menstruasi. Pada 2018, dilakukan pula penelitian di SMP N 19 oleh Tantry et al., (2019) hanya $30,9 \%$ yang mempunyai pengetahuan baik mengenai personal hygiene di SMPN 13 Bandung tahun 2016.

B. Gambaran Sikap Terhadap Personal hygiene Saat Menstruasi Remaja Putri SMP Negeri 3 Parongpong Kabupaten Bandung Barat
Setelah dilakukan proses penelitan kepada responden, didapatkan bahwa sebesar $51,5 \%$ dari total responden memiliki sikap yang mendukung terhadap personal hygiene saat menstruasi. Notoadmodjo (2010) berpendapat bahwa sikap adalah suatu bentuk kesiapan atau kemauan seseorang dalam bertindak dan tidak berarti melaksanakan motif tertentu. Bisa dikatakan bahwa sikap bukan sesuatu yang berfungsi sebagai tindakan atau yang disebut dengan reaksi terbuka maupun aktifitas. Sikap adalah predisposisi tindakan atau yang disebut dengan reaksi tertutup. Disamping itu faktor lain yang sangat penting yang akan mendukung perilaku tersebut diantaranya adalah sarana fasilitas yang memadai, begitu juga dengan perilaku yang baik dan ramah dari petugas kesehatan.

Sikap adalah suatu hasil dari perasaan yang bisa disebut reaksi dari sebuah perasaan. Dalam kata lain bahwa sikap seseorang mengenai sebuah benda atau objek dan suatu perasaan yang bersifat cenderung untuk memihak dan mendukung maupun perasaan yang cenderung untuk tidak memihak dan mendukung objek tersebut. Sikap dapat disebut juga sebagai kesiapan seseorang untuk melakukan aksi ketika berhadapan dengan suatu masalah maupun objek dengan cara mereka masing-masing. Kesiapan yang didefiniskan disini adalah suatu sifat yang cenderung untuk bereaksi ketika seseorang dihadapkan pada suatu kondisi yang dapat merangsang atau memberikan stimulus. Sikap yang bersifat positif akan secara langsung mampu mendorong seseorang untuk berperilaku dan bersikap positif juga (Azwar, 2011).

Menurut Azwar (2007) sikap dipengaruhi oleh pengalaman pribadi dan pengaruh orang terdekat. Selain itu kebudayaan juga dapat mempengaruhi sikap. Pengaruh dari sebuah kebudayaan, lembaga pendidikan, media, dan faktor emosional juga dapat mempengaruhi sikap seseorang.

Hasil penelitian yang didapat dari responden sangat berpengaruh terhadap sikap responden, salah satunya mengenai akibat tidak memelihara organ genital, akan menimbulkan keinginan untuk jauh berpikir dan berupaya keras agar terhindar dari dampak yang menimbulkan berbagai penyakit. Emosi dan keyakinan merupakan komponen dari berpikir ikut berperan sehingga responden memiliki kemauan dalam merawat serta memelihara organ genital dengan baik upaya terhindar dari dampak tersebut.

Pengetahuan saja tidak akan selalu menghasilkan sikap yang mendukung, tetapi ketika ada tekad dan dorongan hati seseorang untuk secara langsung bertindak terhadap suatu objek maupun keadaan internal (Azwar, 2011). Sikap dari remaja putri beserta pemahaman tentang masa menstruasi dapat meningkat dengan adanya informasi yang terpercaya dan akurat, sehingga nantinya akan meminimalkan kurangnya informasi dan keluhan yang nantinya akan dihadapi. (Thakre et al., telah melakukan penelitian pada tahun 2011) tentang bagaimana seorang remaja putri 
mendapatkan informasi mengenai menstruasi. Dari penelitian tersebut didapatkan bahwa sebanyak $71,33 \%$ mendapatkan informasi melalui ibu mereka.

Sikap yang tidak mendukung pun ditunjukkan hampir setengahnya dari responden. Pengalaman pribadi membuat responden belum terlalu berpengalaman dalam mengatasi hal-hal yang berkaitan dengan personal hygiene ketika proses menstruasi dikarenakan hal tersebut merupakan hal yang baru yang mereka dapatkan. Responden yang digunakan dalam penelitian memiliki usia rata-rata sebesar 13 dan 14 tahun dan usia manarche responden sekitar usia 12 dan 13 tahun. Antara ibu dan rmaja putri harus saling membangun sikap hidup bersih terutama pada masa menstruasi dan bila ada yang sulit dipahami mengenai menstruasi sebaiknya berkonsultasi pada tenaga kesehatan. Hasil temuan untuk sikap remaja putri SMP N 3 Parongpong Kabupaten Bandung Barat terhadap personal hygiene pada saat menstruasi menunjukkan hasil yang mendukung yang mana tenaga kesehatan tetap harus melaksanakan promosi kesehatan dengan baik untuk mendorong sikap yang baik dari para remaja putri terutama disekolah-sekolah.

Faktor lain yang sangat mempengaruhi personal hygiene pada saat menstruasi adalah faktor kebudayaan. Seperti beberapa mitos yang saat ini dipercaya contohnya membatasi aktivitas sehari-hari, menghindari minuman dingin yang pada saat menstruasi serta tidak boleh keramas saat menstruasi. Berdasarkan hasil penelitian ini, 40\% dari subvariabel keyakinan atau kepercayaan mengenai personal hygiene ketika terjadi menstruasi oleh responden ditunjukkan kurang mendukung. Banyaknya anggapan mitos-mitos negatif yang ada di masyarakat mengenai topik menstruasi pada wanita yang masih menjadi hal yang tabu dan menganggap sebagi sesuatu yang memalukan untuk dibahas. (Rajakumari G, 2015). Dilihat dari segi kecenderungan untuk bertindak 35,5\% memiliki sikap yang tidak mendukung terhadap personal hygiene pada saat menstruasi.

\section{Gambaran Perilaku Terhadap Personal hygiene Saat Menstruasi Remaja Putri SMP Negeri 3 Parongpong Kabupaten Bandung Barat}

Berdasarkan hasil data yang diperoleh, didapati perilaku respoden sebagian besar dalam kategori kurang sebesar $(68,5 \%)$ dalam hal perilaku yang berkaitan dengan personal hygiene pada saat menstruasi. Lawrence Green (1980 dalam Mubarak, 2011) berteori bahwa perilaku personal hygiene terdiri dari dua aspek. Dua faktor tersebut diantaranya adalah faktor perilaku (behavior causes) dan faktor diluar perilaku (nonbehavior causes). Beberapa faktor yang menyebabkan terbentuknya perilaku antara lain : Pertama Predisposing factor yaitu faktor dasar seseorang melakukan sesuatu meliputi keyakinan, norma-norma, kepercayaan, ilmu pengetahuan, sikap, dan lain-lain. Kedua adalah Enabling factor merupakan faktor yang memfasilitasi perilaku, diantaranya adalah sarana kesehatan. Ketiga Reinforcing faktor yaitu faktor yang menguatkan terjadinya perilaku pada seseorang, diantaranya adalah sikap dan perilaku dari seorang tokoh masyarakat maupun petugas kesehatan.

SMP Negeri 3 Parongpong ini memiliki faktor-faktor pendukung untuk para remaja putri agar mempunyai perilaku personal hygiene ketika proses menstruasi yang cukup baik. Contohnya dalam faktor predisposisi yaitu salah satunya pengetahuan, disekolah ini telah memfasilitasi dengan memberikan penyuluhan kesehatan reproduksi yang dilaksanakan oleh petugas Puskesmas yang berada tepat disebelah sekolah. Hanya saja saat penyuluhan dilaksanakan oleh petugas, tidak seluruh siswi putri dapat mengikuti kegiatan tersebut melainkan hanya dua orang yang mewakili perkelas. Faktor pendukung yaitu salah satunya lingkungan fisik, disekolah ini belum memfasilitasi tempat cuci tangan, alat pengering seperti tisu, dan stok pembalut ditoilet para siswi. Artinya masih banyak siswi yang belum menunjukkan perilaku yang baik dalam personal hygiene ketika terjadi menstruasi, ini perlu mendapatkan perhatian dari ibu, guru serta petugas kesehatan sehingga dapat bekerjasama dengan pihak sekolah. Hasil temuan untuk perilaku remaja putri SMP N 3 Parongpong Kabupaten Bandung Barat terhadap personal hygiene pada saat menstruasi menunjukkan hasil yang kurang baik yang mana tenaga kesehatan harus meningkatkan promosi kesehatan untuk mewujudkan perilaku yang baik dari para remaja putri.

Pengetahuan dari seseorang sangat dipengaruhi oleh beberapa faktor utama, diantaranya adalah budaya, pengetahuan, kepercayaan, sikap, dan sejenisnya yang berasal dari orang tua maupun masyarakat sekitarnya. Selain itu dalam mendukung serta memperkuat terbentuknya perilaku dan kebiasaan, dibutuhkan kontribusi dan kerja sama dari para petugas kesehatan untuk menyediakan fasilitas yang layak dan layanan yang baik (Notoatmodjo, 2007). Perawatan diri terkait dengan menstruasi diantaranya ganti celana dalam yang menyerap 2 kali sehari, batasi konsumsi lemak dan pemakaian garam, serta perbanyak minum air putih, mencukur dan merapikan rambut kemaluan (Rosyida ,2019).

Hal ini dapat dilihat dapat dilihat juga banyaknya keluhankeluhan yang dirasakan responden saat menstruasi, seperti kram atau nyeri perut $(69,6 \%)$, gatal-gatal $(9,8 \%)$, pusing $(8,7 \%)$, pegal-pegal $(6,5 \%)$, tercium bau tidak sedap (3,3\%). Dari segi komponen sikap yaitu $40 \%$ keyakinan atau kepercayaan yang berkaitan dengan personal hygiene ketika proses menstruasi oleh responden menunjukkan bahwa tidak mendukung. 
Penelitian yang dikerjakan oleh peneliti, berhubungan dan memiliki hasil yang sama dengan hasil penelitian yang dikerjakan oleh Novianti et al., (2016) di SMP negeri Satap Bukti Tahun 2016, menunjukkan sebanyak (81,8\%) responden memiliki perilaku yang kurang dalam personal hygiene ketika menstruasi. Penelitian kali ini juga memiliki hasil yang sama dengan hasil penelitian yang telah dikerjakan oleh Nicky \& Ajeng (2016) di SMP Patriot dengan jumlah $70,6 \%$ reponden belum mempunyai perilaku yang cenderung baik dan mengerti yang berkaitan dengan personal hygiene ketika terjadi menstruasi. Hasil penelitian tersebut juga menghasilkan kesimpulan yang sama dengan hasil penelitian yang dikerjakan oleh Yamin et al., (2019) di Pesantren Ummul Mukminin Kota Makasar) menunjukkan sebanyak $67,3 \%$ respondn sudah mengerjakan dan menunjukkan perilaku personal hygiene yang kurang baik.

\section{Kesimpulan dan Saran}

Berdasarkan dari hasil penelitian yang telah dilakukan mengenai pengetahuan, sikap dan perilaku remaja putri terhadap personal hygiene pada saat menstruasi di SMP Negeri 3 Parongpong Kabupaten Bandung Barat, dapat

\section{Daftar Pustaka}

Andarmoyo, S. (2012). Personal Hygiene. In yogyakarta. Graha Ilmu.

Azwar, S. (2011). Sikap Manusia Teori Dan Pengukurannya. Pustaka Pelajar.

Desmita. (2009). Psikologi Perkembangan Peserta Didik. Remaja Rosdakarya.

Eswi, A., Helal, H., \& Elarousy, W. (2012). Menstrual Attitude and Knowledge among Egyptian Female Adolescents. Journal of American Science, 8(6), $555-565$.

Liza, L. (2019). Gambaran Pengetahuan dan Sikap Remaja Putri terhadap Personal Higiene saat Menstruasi di SMP N 19 Kota Jambi Tahun 2018. Jurnal Akademika Baiturrahim Jambi, 8(2), 267275. https://doi.org/10.36565/jab.v8i2.168

Mubarak, W. I. (2011). Promosi Kesehatan untuk Kebidanan. Salemba Medika.

Nicky, \& Ajeng. (2016). Hubungan Pengetahuan dan Sikap Terhadap Perilaku Personal Hygiene Mentruasi. Jurnal Ilmu Kesehatan Masyarakat.

Notoadmodjo. (2010). Ilmu Perilaku Kesehatan. Rineka Cipta. disimpulkan bahwa hasil pengetahuan responden terhadap personal hygiene ketika proses menstruasi sebagian besar $(95,7 \%)$ dalam ketegori kurang baik. Hasil sikap responden terhadap personal hygiene pada ketika proses menstruasi sebagian besar $(51,1 \%)$ dalam kategori mendukung. Hasil perilaku responden terhadap personal hygiene ketika proses menstruasi sebagian besar $(68,5 \%)$ dalam kategori kurang baik.

Diharapkan dapat menjadi masukan bagi pihak sekolah dalam memberikan fasilitas di sekolah seperti tempat mencuci tangan, alat pengering berupa tisu dan ketersediaan pembalut di toilet wanita untuk menanamkan pentingnya perilaku personal hygiene saat menstruasi dengan baik. Bekerjasama dengan perawat dan tenaga kesehatan lainnya sebagai upaya dini untuk memberikan promosi kesehatan tentang pentingnya personal hygiene pada remaja putri saat mestruasi, sehingga informasi yang didapat menjadi acuan untuk mengaplikasikannya di kehidupan sehari-hari juga mengurangi keluhan yang dialami remaja putri pada saat menstruasi

Notoatmodjo, S. (2007). Promosi Kesehatan dan Ilmu Perilaku. Rineka Cipta.

Notoatmodjo, S. (2012). Promosi kesehatan dan perilaku kesehatan. Rineka Cipta.

Novianti, S, Y., \& Erawan, P. E. M. (2016). Hubungan Pengetahuan, Sikap, Dan Tindakan Dengan Personal Hygiene Menstruasi Pada Remaja Putri Di Smp Negeri Satap Bukit Asri Kabupaten Buton Tahun 2016. Jurnal Ilmiah Mahasiswa Kesehatan Masyarakat Unsyiah, 1(3), 1-10.

Nugroho, T. (2013). Masalah Kesehatan Reproduksi. Medical Book.

Poltekkes Depkes Jakarta I. (2010). Kesehatan Remaja: Problem dan Solusinya. Salemba Medika.

Pythagoras, K. C. (2017). PERSONAL HYGIENE REMAJA PUTRI KETIKA MENSTRUASI

Katarina Canggih Pythagoras Perencanaan Pembangunan Nasional pada. Jurnal PROMKES, 5(1), 12-24.

Rajakumari G, A. (2015). A study on knowledge regarding menstrual hygiene among adolescent school girls. Global Journal of Current Research, 111-116.

Rosyida, C. A. D. (2019). Buku Ajar Kesehatan Reproduksi Remaja dan Wanita. Pt.Pustaka Baru. 
Santina, T., Wehbe, N., Ziade, M. F., \& Nehme, M. (2013). Assessment of Beliefs and Practices Relating to Menstrual Hygiene of International Journal of Health Sciences and Research Assessment of Beliefs and Practices Relating to Menstrual Hygiene of Adolescent Girls in Lebanon. International Journal of Health Sciences and Research, 3(12), 75-88.

Solehati, T., Trisyani, M., \& Kosasih, C. E. (2018). Gambaran Pengetahuan, Sikap, Dan Keluhan Tentang Menstruasi Diantara Remaja Puteri. Jurnal Keperawatan Komprehensif, 4(2), 86. https://doi.org/10.33755/jkk.v4i2.110

Tantry, Y. U., Solehati, T., \& Yani, D. I. (2019). GAMBARAN PENGETAHUAN, SIKAP, DAN PERILAKU PERAWATAN DIRI SELAMA MENSTRUASI PADA SISWI SMPN 13 BANDUNG. Jurnal Ilmu Keperawatan Dan Kebidanan, 10(1), 146-154.

Thakre, S. B., Thakre, S. S., Reddy, M., Rathi, N., Pathak, K., \& Ughade, S. (2011). Menstrual hygiene: Knowledge and practice among adolescent school girls of Saoner, Nagpur District. Journal of Clinical and Diagnostic Research, 5(5), 1027-1033.

Widyastuti, Y., Rahmawati, A., \& Purnamaningrum, Y. (2009). Kesehatan Reproduksi. Fitramaya.

Yamin, R. A., Pratiwi, E., \& Amalia, M. (2019). ANALISIS HUBUNGAN SIKAP TERHADAP PRAKTIK HIGIENE MENSTRUASI PADA SISWA PEREMPUAN DI PESANTREN UMMUL MUKMININ KOTA MAKASSAR TAHUN 2019. JURNAL KESEHATAN MASYARAKAT MULAWARMAN, 1(2), 40-45. 